\title{
X-ray test on passion fruit seeds submitted to different aryl removal methods
}

\author{
Rogerio Luciano Severiano', Paloma Rayane Pinheiro', \\ 'Federal University of Rio Grande do Norte, Natal, Brazil \\ ${ }^{2}$ University of São Paulo, Piracicaba, Brazil \\ *Corresponding author, email: marcioagron@yahoo.com.br
}

Francisco Guilhien Gomes Junior², Andre Dantas de Medeiros' ${ }^{1}$ Marcio Dias Pereira ${ }^{*}$

\begin{abstract}
Passion fruit seeds present germination problems which are mainly attributed to growth regulating substances present in aryl. The objective of this work was to evaluate the quality of passion fruit seeds submitted to different aryl removal methods by the X-ray test compared to the traditional viability and vigor tests. Seeds extracted from giant yellow passion fruit were purchased from a local market and then subjected to the following aryl removal techniques: water degumming, sand rubbing, mechanical blending, fermentation and virgin lime. After aryl removal, the seeds were submitted to a physiological quality evaluation by the moisture degree, germination, first germination count, germination speed, and seedling length, and also a physical quality evaluation by $\mathrm{X}$-ray test. The treatments using fermentation and virgin lime were harmful to the seeds and the aryl removal techniques of passion fruit seeds by means of degumming in water, sand friction and mechanically with a blender presented the best results. The X-ray test was efficient in identifying mechanical damage and deformations in passion fruit seeds.
\end{abstract}

Keywords: Imaging analysis, Passiflora edulis, physical quality, vigor

\section{Introduction}

Passion fruit seeds present germination problems, as reports by producers observing low and uneven germination by multiplying the passion fruit by seeds are common, thereby causing problems in seedling formation (Martins et al., 2006).

Problems in passion fruit seed germination may mainly occur due to the negative effect of growth regulating substances present in aryl, a mucilaginous layer that surrounds the seeds of this species (Osipi et al., 2011). Aryl can also act as a barrier to water entry into the seeds and as a culture medium which favors the development of harmful microorganisms to the seeds, and therefore it is necessary to remove it in order to improve the viability and vigor parameters (Martins et al., 2010).

A number of methods are recommended for aryl removal in passion fruit seeds such as water fermentation (Silva et al., 2015), using a blender (Ferreira et al., 2007), seed friction mixed with sand (Aguiar et al., 2014), degumming in water (Aguiar et al., 2014) and immersion in virgin lime solution (Martins et al., 2006). Implementing these techniques aims to improve the seed performance; however, some negative effects may occur due to inadequate performance of the procedures/techniques, leading to physical or physiological damage occurring. 
Damage to physical and physiological quality caused to passion fruit seeds subjected to aryl removal methods is generally difficult to identify since they may not be visible and may have latent effects (Silva et al., 2015). An alternative for accurately evaluating these seeds is to use X-ray imaging analysis techniques to identify mechanical damage and seed deformations.

The $x$-ray imaging technique enables visualizing seeds with insect damage and fractures or cracks due to mechanical damage caused by pre and post-harvest factors (Pupim et al., 2008; Menezes et al., 2012). The test is fast, simple, efficient and the seeds' viability is not compromised by exposure to X-rays, which enables their use in other tests (Pinto et al., 2009; Marcos Filho et al., 2010). X-ray analysis has been used for several purposes, with one of them being as a complement to the germination test.

The objective of this work was to evaluate the quality of passion fruit seeds submitted to different aryl removal methods by the x-ray test, and compare the evaluation to traditional viability and vigor tests.

\section{Material and Methods}

This work was conducted from September to December 2016 at the Seed Analysis and Image Analysis Laboratory of the "Luiz de Queiroz" School of Agriculture Plant Production Department, University of São Paulo - Esalq/USP, in Piracicaba, SP.

Seeds were obtained from giant yellow passion fruit fruits acquired from a local market, all with the same ripeness appearance and without any damage or signs of pests or diseases.

For the seed extraction, the fruits were cut in half using a knife and all the pulp containing seeds was removed. The seeds mixed with pulp were homogenized in a container to form a single sample and then separated into five equal $250 \mathrm{~mL}$ sub-samples, and then subjected to the following aryl removal techniques: degumming with water - the sub-sample was mixed with $1 \mathrm{~L}$ of water and then "macerated" with hands to separate the aryl from the seeds; friction with sand - the sub-sample was mixed with an equal amount of sand, which was then rubbed with hands for 30 minutes; mechanical with a blender - the sub-sample was placed in a blender with its blades protected with insulation tape, the beaker volume was filled to 1,250 mL (maximum volume) with water, then the pulsar function was activated for 1 second, and whenever the mixture stopped circulating, the pulse function was activated again for 1 second, with this process being repeated 10 times; fermentation the sub-sample was mixed with distilled water in a glass container in an amount equivalent to $50 \%$ of the pulp volume and put to ferment at room temperature for 3 days; virgin lime solution - the sub-sample was mixed into $1 \mathrm{~L}$ of a $10 \%$ virgin lime based aqueous solution for $10 \mathrm{~min}$.

The seeds were subjected to successive washing in sieves under running water at the end of each treatment to facilitate separating the aryl from the seeds, and then put to dry in the shade on paper towel sheets in a natural laboratory environment ( $38 \% \mathrm{RH}, 25^{\circ} \mathrm{C}$ ) for 24 hours.

The seeds of each treatment were submitted to a moisture degree determination (Brazil, 2009) and to physiological characterization by the following tests: germination test (G) the seeds were distributed on two sheets of germitest ${ }^{\oplus}$ paper, and then covered with a third which formed rolls. The paper was moistened with distilled water in the amount equivalent to 2.5 times the dry paper's mass. The evaluations were performed daily beginning on the first day after sowing and finishing on the twenty-eighth day, only considering seeds as germinated as those which produced normal seedlings (Brazil, 2009); first germination count (FGC) performed in conjunction with the germination test, computing the percentage of normal seedlings obtained on the $7^{\text {th }}$ day after sowing (Brasil, 2009); germination speed (GS) - was determined by daily counts (at the same time of the day) of the number of seeds that emitted a primary root of $1 \mathrm{~cm}$ from the first to the last day of the germination test implementation. The germination speed was expressed in the form of the germination speed index (GSI), calculated according to the equation proposed by Maguire (1962); seedling length - performed using 4 replicates of 20 seeds distributed in rolls of paper following the same recommendation for the 
germination test, and at the end of the test the root length (RL), shoot length (SL) and total length (TL) of the seedlings were determined using a ruler graduated in millimeters with the results expressed in centimeters $(\mathrm{cm})$.

X-ray analysis associated with seed germination: 200 seeds (eight subsamples of 25) were radiographed for each treatment using a Faxitron model MX-20 DC 12 digital X-ray device coupled to a Core 2 duo computer $(3.16 \mathrm{GHz}, 3$ GB of RAM, Hard Disk $160 \mathrm{~GB})$. The seeds were radiographed at a distance of $14.3 \mathrm{~cm}$ from the $X$-ray emission source. The seeds were arranged on transparent double sided tape adhered on an overhead transparency sheet which was placed on acrylic plate inside the equipment in order to better position them inside the apparatus. After radiography, the seeds were put to germinate in the same order in which they were radiographed according to the previously described methodology for the germination test. Twenty-eight days after the test set-up, normal seedlings as well as abnormal seedlings and dormant or dead seeds were scanned using an HP Scanjet $200^{\circledR}$ scanner. The germination results were compared with the radiographic image of each seed.
Radiographic images were analyzed to obtain the number of seeds damaged in each treatment. The seeds of each treatment were classified into five categories: (1) well-formed, (2) deformed, (3) empty, (4) mechanically damaged and (5) hard or dead, where seeds which fell into the first category but did not germinate were classified in the latter class.

A completely randomized design with 5 treatments and four replicates of 50 seeds was implemented. The data were submitted to analysis of variance at $5 \%$ by the F-test, and the means (Tukey 5\%) were compared when significant. The R-Project V. 3.1.0 statistical software program (R Development Core Team, 2014) was used in the statistical analyzes.

\section{Results and Discussion}

It was observed that seed germination was not affected regardless of the technique used to remove aryl (Table 1). In contrast to the results obtained in the present study, Aguiar et al. (2014) observed that sand friction and water degumming promoted better germination results when compared to other treatments in analyzing the effect of different aryl removal methods on Passiflora edulis seeds.

Table 1. Germination (G), first germination count (FGC), germination speed index (GSI), total seedling length (TL), shoot length (SL) and root length (RL) of seedlings from passion fruit seeds submitted to different aryl removal techniques.

\begin{tabular}{|c|c|c|c|c|c|c|}
\hline Treatments & $G(\%)$ & FGC (\%) & GSI & $\mathrm{TL}(\mathrm{cm})$ & $\mathrm{SL}(\mathrm{cm})$ & $\mathrm{RL}(\mathrm{cm})$ \\
\hline Water & $98 a^{1}$ & $41 a b$ & $4.22 \mathrm{ab}$ & $21.66 \mathrm{a}$ & $10.63 a$ & $11.03 \mathrm{a}$ \\
\hline Sand & $96 a$ & $52 a$ & $4.32 \mathrm{a}$ & $21.42 \mathrm{a}$ & $11.35 \mathrm{a}$ & $10.06 \mathrm{a}$ \\
\hline Blender & $97 \mathrm{a}$ & 52 a & $4.43 \mathrm{a}$ & $20.80 a b$ & $11.11 \mathrm{a}$ & $9.69 \mathrm{ab}$ \\
\hline Fermentation & $96 a$ & $25 \mathrm{c}$ & $3.79 \mathrm{c}$ & $19.56 \mathrm{~b}$ & $11.03 \mathrm{a}$ & $8.53 \mathrm{~b}$ \\
\hline Lime solution & $98 \mathrm{a}$ & $32 \mathrm{bc}$ & $4.02 \mathrm{~b}$ & $20.8 \mathrm{ab}$ & $11.14 \mathrm{a}$ & $9.66 \mathrm{ab}$ \\
\hline CV\% & 1.69 & 16.06 & 2.52 & 3.8 & 5.85 & 6.68 \\
\hline SD & 3.60 & 14.20 & 0.22 & 1.73 & 1.41 & 7.53 \\
\hline $\mathrm{F}$ & 1.57 & 13.91 & 23.24 & 4.23 & 0.67 & 1.42 \\
\hline
\end{tabular}

Means followed by the same letter in the column do not differ by Tukey test at $5 \%$ probability.

In the present study, the low exposure time of the seeds to the blender together with the protection of the blades may have contributed to avoid possible damage to seed germination; however, the exposure time seems to be the most important when using this technique. For example, even with protection of the blades, Martins et al. (2006) used an uninterrupted time of 20 seconds, and Osipi et al. (2011) opted to push the pulsar button 50 times; in both studies, the authors observed low germination values even until destroying the $P$. edulis seeds.

In the case of fermentation where its effect on germination was not observed (Table 1), it can be suggested that the use of three days was not detrimental to seed quality, as suggested by Cardoso et al. (2001) for P. edulis seeds. Even by submitting the seeds to fermentation for six days, Osipi et al. (2011) also did not observe reduced germination for this species. A positive response 
was observed in terms of germination in seeds of other species such as Crataeva tapia when submitted to the mucilage extraction method by fermentation in 3 days (Santos Moura et al., 2014). These results suggest that the negative effect of fermentation on the viability of passion fruit seeds only occurs when they are submitted to a longer time period in the fermentation process.

Chemical scarification with the use of the virgin lime solution also did not promote differences in the germination compared to the other treatments (Table 1). The literature still shows divergent results regarding the use of this technique; in using a $10 \%$ virgin lime solution, Martins et al. (2006) also observed good germination results in $P$. edulis, while Osipi et al. (2011) verified reduced germination and a large number of abnormal seedlings using this same solution in Passiflora alata seeds, which may mean different genetic sensitivity for this type of treatment.

When the initial seedling development was evaluated by the first germination count (FGC) and the germination speed index (GSI) (Table 1), it was observed that the treatments using water, sand and the blender for aryl removal did not affect the vigor evaluated via these two variables, which measure the seeds' germination speed. Similar results were observed by Aguiar et al. (2014) in P. edulis seeds when using sand friction, as they found a higher seedling emergence rate in seeds treated with water and water plus sand. Regarding the mechanical removal with the blender, in the same way the low exposure time to the friction of the blades did not affect the germination, this might also not have affected the seeds' germination speed.

The treatments for aryl removal by fermentation and virgin lime solution adversely affected the parameters related to germination speed, increasing the time required for seed germination. Similar results were observed by Cardoso et al. (2001) in testing the fermentation technique in $P$. edulis seeds, which verified that the higher the fermentation time, the lower the germination speed index. On the other hand, Silva et al. (2015) observed a significant and positive fermentation effect in relation to the mechanical method for emergence speed when also comparing aryl removal methods in $P$. edulis.

Seedling and root length (Table 1) were also affected by the fermentation and virgin lime treatments. This is mainly due to the seedlings' initial development which is closely linked to the germination process and its unfolding. Thus, negative effects usually occur in the initial development of the seedlings when the germination metabolism is affected by the pregermination treatment (Marcos Filho, 2015).

The low moisture content found in passion fruit seeds enabled good visualization of its internal morphology (Table 2). It is known that the moisture degree of the seeds has an influence on the optical density of X-ray images; in evaluating Terminalia angentea seeds, Gomes et al. (2014) verified that the low water content in the seeds (9.2-10.1\%) led to a higher optical density, thereby enabling better internal morphology visualization of the radiographed seeds.

The X-ray images enabled classifying the seeds in the five pre-determined categories, as can be observed in Table 2 and Figure 1.

Table 2. Moisture Degree (MD) and percentage of seeds classified in each seed category after the X-ray test and submitted to different aryl removal methods.

\begin{tabular}{lcccccc}
\hline \multirow{2}{*}{ Categories } & \multicolumn{7}{c}{ Treatments } \\
\cline { 2 - 7 } & MD & Water & Sand & $\begin{array}{c}\text { Blender } \\
\%\end{array}$ & Fermentation & Lime \\
\hline Well-formed & 7.04 & 98.5 & 98.0 & 99.5 & 96.5 & 97.5 \\
Deformed & 7.03 & 1.5 & 1.0 & 0.0 & 1.5 & 1.0 \\
Empty & 8.05 & 0.0 & 0.0 & 0.0 & 0.5 & 0.0 \\
Mechanical damage & 8.01 & 0.0 & 0.5 & 0.5 & 1.0 & 0.0 \\
Hard or dead & 7.77 & 0.0 & 0.5 & 0.0 & 0.5 & 1.5 \\
\hline
\end{tabular}

According to Pinto et al. (2009), well-formed seeds usually originate normal seedlings, whereas there is a high relation between the occurrence of deformed seeds and the percentage of abnormal seedlings and dead seeds. 


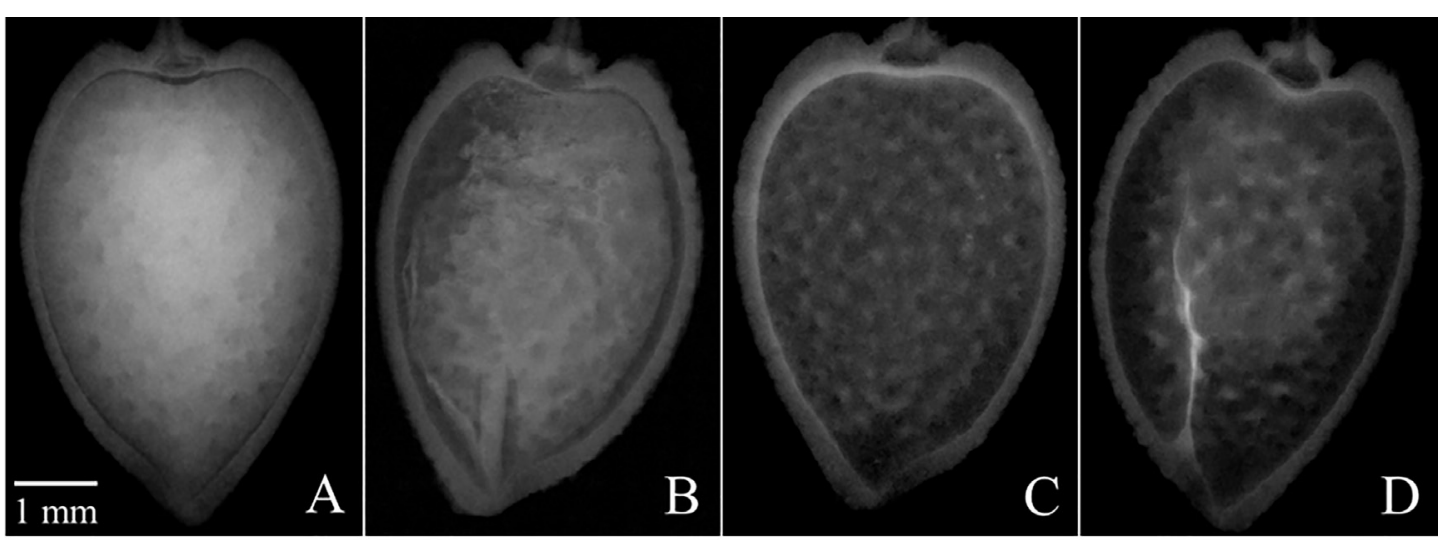

Figure 1. Visual classification of passion fruit seeds generated by X-ray analysis: (A) well-formed seeds; (B) deformed; (C) empty; and (D) mechanically-damaged.

According to some authors such as Pupim et al. (2008) and Silva et al. (2014), seeds classified as well-formed by the X-ray technique may grow to be abnormal seedlings and even dead seeds, since radiography allows to verify whether or not there is tissue malformation, but does not necessarily establish a direct relationship with physiological processes.

By classifying the seeds into categories, it was possible to identify that most of the seeds fit into the well-formed category in all the tested methods (Table 2).

These results corroborate those obtained in the germination test for the seeds submitted to the different aryl removal treatments, in which almost all the seeds grew into normal seedlings, resulting in germination values ranging from 96 to $98 \%$. The sum of the other categories represents a minimal percentage within the treatments, reaching a maximum of $3.5 \%$. Thus, X-rays are presented as an alternative for classifying seeds of this species, enabling to identify deformed and empty seeds, and further improving the quality of samples or batches. Silva et al. (2014) obtained similar results for pumpkin seeds.

Using the X-ray technique with the objective of identifying possible mechanical damage caused by the treatments revealed that only four seeds presented damage (cracks) (Figure 2). Two of these seeds were found in the fermentation treatment, and the others in the sand and blender treatments; however, the analysis revealed that the damaged seeds were empty. Thus, it is possible to infer that the chance of mechanical damage occurring by the implemented treatments is quite small under the conditions in which this research was conducted, since the maximum amount of damaged seeds found was $2 \%$ in all the tested techniques, and so these seeds were no longer viable.
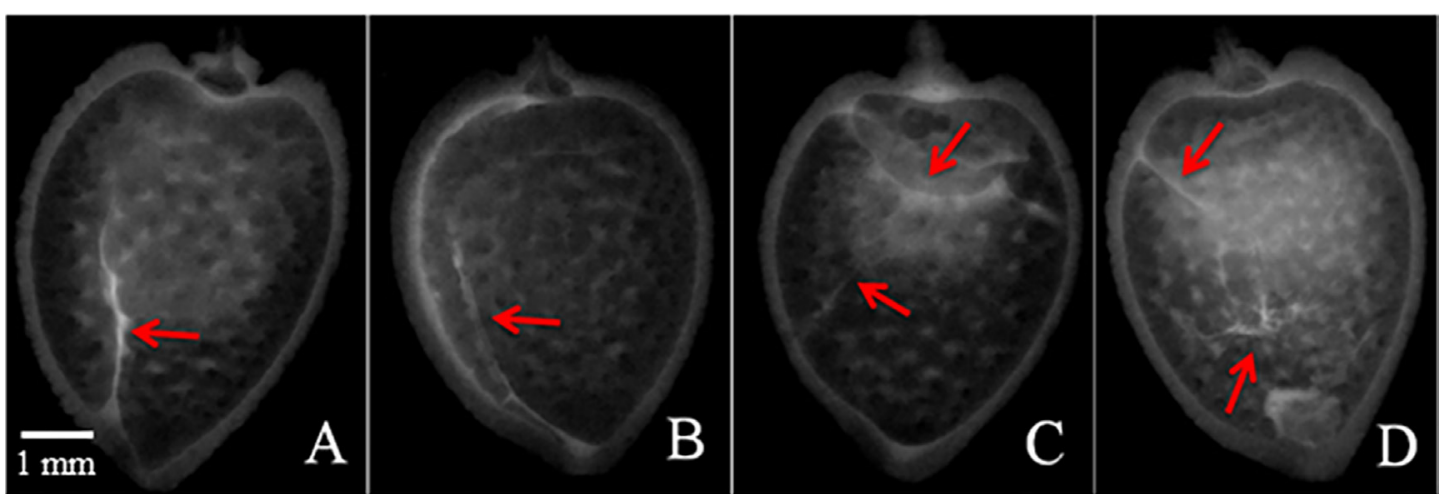

Figure 2. Radiographic images of empty and cracked passion fruit seeds after being submitted to aryl removal treatments: (A, B) fermentation; (C) sand; and (D) blender.

In comparing the radiographic images with the germination test, it was possible to identify that some deformed seeds may give rise to non-germinated seeds and in some cases may even germinate, but the formed seedlings are abnormal (Figure 3). This was also observed by Carvalho et al. (2009) and Pupim et al. (2008), who emphasize that these seeds usually give rise 
to abnormal seedlings or dead seeds.

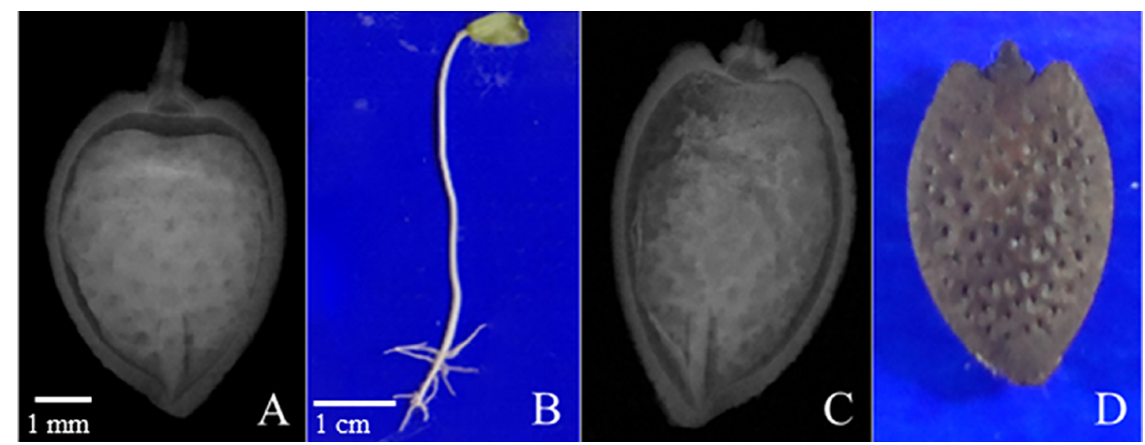

Figure 3. Radiographic images of: $(A, C)$ deformed passion fruit seeds, which gave rise to (B) abnormal seedlings and (D) dead seeds at the end of the germination test.

\section{Conclusions}

The aryl removal techniques of passion fruit seeds by means of degumming in water, sand rubbing and mechanical blender showed the best results.

$X$-ray analysis was efficient in evaluating the physical quality of seeds, aiding in detecting mechanical damage, empty seeds and seed deformation.

\section{References}

Aguiar, R., Zaccheo, P., Stenzel, N., Sera, T., Neves, C. 2015. Produção e qualidade de frutos híbridos de maracujazeiro-amarelo no norte do Paraná. Revista Brasileira de Fruticultura 37: 130137.

Brasil. Ministério da Agricultura, Pecuária e Abastecimento. 2009. Regras para Análise de Sementes. MAPA/ACS, Brasília, Brasil. 399 p.

Cardoso, G.D., Tavares, J.C., Ferreira, R.L.F., Câmara, F.A.A., Carmo, G.D. 2001. Desenvolvimento de mudas de maracujazeiroamarelo obtidas de sementes extraídas por fermentação. Revista Brasileira de Fruticultura 23: 639-642.

Carvalho, M.L.M.D., Silva, C.D.D., Oliveira, L.M.D., Silva, D.G., Caldeira, C.M. 2009. Teste de raios $X$ na avaliação da qualidade de sementes de abóbora. Revista Brasileira de Sementes 31: 221227.

Ferreira, G., Costa, P.N., Ferrari, T.B., Rodrigues, J.D., Braga, J.F., Jesus, F.A.D. 2007. Emergência e desenvolvimento de plântulas de maracujazeiro azedo oriundas de sementes tratadas com bioestimulante. Revista Brasileira de Fruticultura 29: 595-599.

Gomes, K.B.P., Martins, R.D.C.C., Martins, I.S., Junior, F.G.G. 2014. Avaliação da morfologia interna de sementes de Terminalia argentea (Combretaceae) pelo teste de raios X. Revista
Ciência Agronômica 45: 752-759.

Maguire, J.D. 1962. Speed of germination-aid in selection and evaluation for seedling emergence and vigor. Crop science 2:176-177.

Marcos Filho, J. 2015. Fisiologia de Sementes de Plantas Cultivadas. Londrina, Abrates. 659 p.

Marcos Filho, J., Gomes Junior, F.G., Bennett, M.A., Wells, A.A., Stieve, S. 2010. Using tomato analyzer software to determine embryo size in $\mathrm{x}$-rayed seeds. Revista Brasileira de Sementes 32: 146-153.

Martins, C.M., Silva Vasconcellos, M.A., Rossetto, C.A.V., Carvalho, M.G. 2010. Prospecção fitoquímica do arilo de sementes de maracujá amarelo e influência em germinação de sementes. Ciência Rural 40: 1934-1940.

Martins, M.R., Reis, M.C., Neto, J.A.M., Gusmão, L.L., Gomes, J.J.A. 2006. Influência de diferentes métodos de remoção do arilo na germinação de sementes de maracujazeiro-amarelo (Passiflora edulis Sims $f$. flavicarpa Deg.). Revista da FZVA 13: 28-38.

Menezes, N.L.D., Cicero, S.M., Villela, F.A., Bortolotto, R.P. 2012. Using $X$ rays to evaluate fissures in rice seeds dried artificially. Revista Brasileira de Sementes 34: 70-77.

Osipi, E.A.F., Lima, C.B., Cossa, C.A. 2011. Influência de métodos de remoção do arilo na qualidade fisiológica de sementes de Passiflora alata Curtis. Revista Brasileira de Fruticultura 33: 680-685.

Pinto, T.L.F., Marcos Filho, J., Forti, V.A., Carvalho, C.D., Gomes Junior, F.G. 2009. Avaliação da viabilidade de sementes de pinhão manso pelos testes de tetrazólio e de raios X. Revista Brasileira de Sementes 31: 195-201.

Pupim, T.L., Novembre, A.D.L.C., Carvalho, M.L.M., Cicero, S.M. 2008. Adequação do teste de Raios X para avaliação da qualidade de sementes de embaúba (Cecropia pachystachya 
Trec.). Revista Brasileira de Sementes 30: 28-32.

R Development Core Team. 2014. R: A language and environment for statistical computing. Versão 3.1.0. R Foundation for Statistical Computing, Vienna, Austria. https://www.R-project.org/< Acesso em 02 Set. 2016>

Santos Moura, S.D.S., Alves, E.U., Galindo, E.A., Moura, M.F.D., Melo, P.A.F.R.D. 2014. Physiological quality of Crataeva tapia L. seeds under different mucilage extraction methods. Revista Brasileira de Fruticultura 36: 686-692.

Silva, P.P., Freitas, R.A., Cícero, S.M., Marcos-Filho, J., NASCIMENTO, W. 2014. Análise de imagens no estudo morfológico e fisiológico de sementes de abóbora. Horticultura Brasileira 32: 210-214.

Silva, S.M., Oliveira, R.C.D., Almeida, R.F.D., Sá Júnior, A.D., Santos, C.M.D. 2015. Aryl removal methods and passion fruit seed positions: Germination and emergence. Journal of Seed Science 37: 125-130. 